\title{
The effect of vaccinating infection during pregnancy and dietary protein supply on the peri-parturient immune response of sheep to infection with Teladorsagia circumcincta and Trichostrongylus colubriformis larvae
}

\author{
A. R. Sykes ${ }^{1 \dagger}$, H. L. Xie ${ }^{1}$, M. Stankiewicz ${ }^{1}$, J. F. Huntley ${ }^{2}$, A. Mackellar ${ }^{2}$, J. R. Sedcole', \\ R. W. McAnulty ${ }^{1}$ and R. Green ${ }^{3}$ \\ ${ }^{1}$ Agriculture and Life Sciences Division, PO Box 84, Lincoln University, Canterbury, New Zealand; ${ }^{2}$ Moredun Research Institute, Pentland Science Park, Penicuik, \\ Midlothian, Scotland; ${ }^{3}$ Wallaceville Animal Research Centre, Upper Hutt, New Zealand
}

(Received 10 October 2006; Accepted 9 November 2006)

It is well established that dietary protein supply can influence the peri-parturient breakdown of immunity to nematode parasites but there is no information on the importance of exposure to nematode larvae during pregnancy for this response. We investigated this by exposing housed pregnant sheep, scanned as carrying two lambs, to a vaccinating infection with a trickle mixed infection of Teladorsagia circumcincta and Trichostrongylus colubriformis larvae (L3) or to no infection during weeks -9 to -4 relative to parturition. At the beginning of week -3 all sheep were treated with anthelmintic to remove any vaccinating worm burden and from week -2 to week +6 received a trickle challenge infection with the same nematodes. Within each vaccinating treatment there were two nutritional treatments (no. $=20$ per subgroup) designed to provide 1.5 or 1.0 and 1.3 or 0.8 of metabolisable protein (MP) requirement during pregnancy and lactation, respectively. Five ewes were necropsied during weeks +1 and +3 to measure worm burdens and mucosal inflammatory cells and the remainder maintained until week +6 . Serum levels of total, IgA and IgE antibodies against $L 3$ antigen of each nematode were measured.

Scanning errors and lamb losses resulted in some ewes carrying and/or rearing only one lamb. Numbers of lambs reared was therefore introduced as a treatment effect. Vaccinating infection delayed the peri-parturient rise in faecal egg count (FEC) by an average of 2 weeks but its effect on FEC during the first 6 weeks of lactation was smaller and less persistent than that of dietary MP supply and single- $v$. twin-suckling.

Populations of both nematodes were lower in association with high MP supply, vaccination and single suckling. These changes were associated with increases in numbers of mucosal mast cells (MMC) as a result of both increased MP supply and vaccination. Evidence for a more rapid return of host ability to limit populations of the abdominal nematode T. circumcincta than of the intestinal nematode T. colubriformis was associated with fewer eosinophils and more globule leucocytes (GL) in abomasal than in intestinal tissue.

None of the serum antibody isotypes was affected by dietary protein supply. Total and IgA antibodies were maintained by a current larval (vaccinating) intake. IgA titres, however, increased progressively during pregnancy, especially in twin-bearing ewes. IgE titres appeared to be sensitive primarily to the reproductive cycle itself, peaking around parturition.

This work supports the conclusion that availability of MP supply influences the recruitment and activity of cells of the immune armoury of the gastro-intestinal tract to nematode parasites. The precise outcome may differ with site and/or nematode species.

Keywords: antibodies, immunity, mucosa, nematodes, nutrition, sheep.

\section{Introduction}

Several studies have indicated that the breakdown in immunity which results in the peri-parturient increase in nematode

\footnotetext{
${ }^{\dagger}$ E-mail: sykes@lincoln.ac.nz
}

faecal egg count (FEC) in sheep can be moderated by dietary protein supply (Donaldson et al., 1998 and 2001; Houdijk et al., 2000, 2001a and b and 2003). Other studies have suggested that degree of exposure to larvae and antigenic stimulation during mid and late pregnancy may influence immune responsiveness and therefore the rise in FEC on 
exposure to larvae in the peri-partum period (Leyva et al., 1982; Stankiewicz and Hadas, 1999). The question then arises as to whether the enhancement of immunity by protein supplementation represents a generally enhanced immune capability or an enhanced ability to respond immunologically to the antigenic stimulus of incoming larvae. This issue is important because sheep production systems in several countries are managed in such a way that ewes may be removed from exposure to larvae for several months during pregnancy, for example as a consequence of winter housing in the northern hemisphere or of grazing of spelled reseeded pastures with low levels of larval contamination in all-grass systems such as employed in New Zealand. In both cases, ewes can be re-exposed to larvae at the time of vulnerability to breakdown of immunity in the peri-partum period and during early lactation on return to contaminated pastures.

This paper describes a study designed to test the hypothesis that larval intake enhances the effect of dietary protein supply in limiting the relaxation of protection to nematode parasites in the peri-parturient ewe. Cells of the immune armoury in the gastro-intestinal tract and humoral immune responses were measured to investigate possible mechanisms of any responses.

\section{Material and methods}

\section{Experimental design}

Eighteen-month-old Coopworth ewes were used. They had been reared on ryegrass-white clover pastures under commercial conditions and would have received anthelmintic treatment at approximately monthly intervals until 8 months of age and then at 12 and 15 and 18 months. Following mating 80 scanned as carrying two lambs were treated with two anthelmintics (Ivomec, $200 \mu \mathrm{g}$ ivermectin per kg live weight (LW); Merial New Zealand Ltd and Levben $(4 \mathrm{mg}$ ricobendzole $+7.5 \mathrm{mg}$ levamisole per $\mathrm{kg} \mathrm{LW}$; Novartis, New Zealand Ltd) and brought indoors into individual pens approximately 9 weeks before parturition.

They were allocated to four groups (no. $=20$ ) in a $2 \times 2$ factorial design incorporating two levels of dietary protein concentration and the presence or absence of a vaccinating nematode infection during weeks -8 to -3 relative to anticipated mean date of parturition. The vaccinating infection comprised an average of $5000 \mathrm{~T}$. circumcincta and $3000 \mathrm{~T}$. colubriformis infective third stage larvae per day, given in three doses each week administered on filter paper by balling gun. All sheep were then treated with an anthelmintic (Systamex, $5 \mathrm{mg}$ Oxfendazole per $\mathrm{kg}$ LW; Schering-Plough Animal Health Ltd, New Zealand) during week -3 relative to parturition to remove worms associated with the vaccinating infection to enable measurement of the comparative response of vaccinated and unvaccinated sheep to a subsequent challenge infection. Previous work (Donaldson et al., 1998 and 2001) suggested that relaxation of immunity would have begun to occur at this stage of pregnancy. The challenge infection was imposed from week -2 relative to parturition until 6 weeks of lactation and comprised an average daily infection with 10000 and 7000 third stage larvae per day of $T$. circumcincta and $T$. colubriformis, respectively, given in three doses each week. These rates of infection (vaccination and challenge infection) are considered to represent relatively large challenges, the former to ensure maximum antigenic stimulation. Comparable rates of infection are, however, possible during winter rationing of ewes in allgrass wintering systems in New Zealand (Familton and McAnulty, 1997). Five animals from each group, selected at parturition to balance groups for day of parturition and number of lambs reared, were necropsied for determination of worm burdens and sampling of abomasal and intestinal mucosal tissues at weeks +1 and +3 after lambing. These times were chosen as previous work had suggested that restoration of the ability of the ewe to limit development of incoming larvae could be occurring during the first few weeks of lactation (McAnulty et al., 2001). The remaining sheep in each group were maintained until week 6 for measurement of FEC. The experimental design is given in Table 1.

\section{Management and sampling}

Animals were offered one of two complete feeds which differed in crude protein concentration, the composition and analysis of which are given in Table 2. The feed was offered in a ratio 2:1 (concentrate: chaffed hay) at rates designed to meet the metabolisable energy (ME) requirements of a twin-bearing ewe of $66.5 \mathrm{~kg} \mathrm{LW}$, the mean live weight of the ewes at housing, based on the recommendations of Agricultural and Food Research Council (AFRC, 1993). The crude protein concentrations were designed to provide 1.0 (low protein; LP) or 1.5 (high protein; HP) of the theoretical metabolisable protein (MP) requirement during pregnancy and about 0.8 (LP) or 1.3 (HP) of MP requirement during lactation according to AFRC (1993). These ratios were chosen in the expectation that AFRC (1993) may underestimate the protein requirement for maintenance of immunity to nematodes in the late pregnant and lactating ewe (Donaldson et al., 2001). The amount offered was adjusted each week to take account of the increasing demand for pregnancy. After lambing and throughout lactation the sheep were offered $3 \mathrm{~kg}$ dry matter (DM) per head per day.

Body weight was recorded immediately before feeding at $0830 \mathrm{~h}$ at weekly intervals until parturition and at less frequent intervals after lambing to minimise disturbance of the lambs. Faeces samples were taken from the rectum each week and nematode eggs counted immediately by the methods described by Xie et al. (2004). Blood samples were collected into plain vacutainers (Becton Dickinson, USA) from the jugular vein prior to feeding every 2 weeks during weeks -9 to -3 relative to parturition, then weekly until week +3 and then during week +6 .

After overnight storage at $14^{\circ} \mathrm{C}$ sera was separated by centrifugation at $2000 \mathrm{~g}$ for $20 \mathrm{~min}$ and stored at $-20^{\circ} \mathrm{C}$. 
Peri-parturient immune response of sheep to infection with $T$. circumcincta and $T$. colubriformis larvae

Table 1 Experimental design and ewe reproductive performance

\begin{tabular}{|c|c|c|c|c|c|c|c|c|c|c|c|}
\hline & & \multirow[b]{3}{*}{$\mathrm{n}$} & \multicolumn{6}{|c|}{ Week relative to parturition } & \multirow[b]{3}{*}{ Ewes lactating } & & \\
\hline \multicolumn{2}{|c|}{ Treatment } & & \multirow{2}{*}{$\begin{array}{c}-10 \\
\Downarrow\end{array}$} & \multirow[t]{2}{*}{-8 to -3} & \multirow[t]{2}{*}{-3} & \multirow[t]{2}{*}{-2 to +6} & \multicolumn{2}{|c|}{${ }_{\text {Necropsied }}^{+3}$} & & \multicolumn{2}{|c|}{ Lambs reared as: } \\
\hline Protein & Vaccination & & & & & & $\mathrm{n}(\mathrm{Tw}: \mathrm{s})^{\dagger}$ & $\mathrm{n}(\mathrm{Tw}: \mathrm{s})^{\dagger}$ & & 1 & 2 \\
\hline $\mathrm{H}$ & + & 20 & A1 & $V \downarrow \downarrow \downarrow$ & $\mathrm{A} 2$ & $C \downarrow \downarrow \downarrow$ & $5(3: 2)$ & $5(3: 2)$ & 20 & 12 & 8 \\
\hline $\mathrm{H}$ & - & 20 & $\mathrm{~A} 1$ & - & $\mathrm{A} 2$ & $C \downarrow \downarrow \downarrow$ & $5(2: 3)$ & $5(2: 3)$ & 19 & 3 & 16 \\
\hline L & + & 20 & A1 & $V \downarrow \downarrow \downarrow$ & $\mathrm{A} 2$ & $C \downarrow \downarrow \downarrow$ & $5(2: 3)$ & $5(2: 3)$ & 19 & 7 & 12 \\
\hline L & - & 20 & $\mathrm{~A} 1$ & - & $\mathrm{A} 2$ & $C \downarrow \downarrow \downarrow$ & $5(3: 2)$ & $5(3: 2)$ & 18 & 7 & 11 \\
\hline 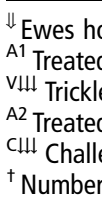 & $\begin{array}{l}\text { sed indoors. } \\
\text { vith two antheln } \\
\text { accinating infec } \\
\text { vith anthelmintic } \\
\text { ge infection with } \\
\text { f ewes and (prop }\end{array}$ & $\begin{array}{l}\text { tics } \\
\text { nn wit } \\
\text { Oxfen } \\
0000\end{array}$ & $\begin{array}{l}\text { mec }+\mathrm{L} \\
000 \mathrm{~T} . \mathrm{c} \\
\text { zole). } \\
\text { circumc } \\
\text { twin:sing }\end{array}$ & $\begin{array}{l}\text { /BZ combinatic } \\
\text { umcincta and } \\
\text { ta and } 7000 \mathrm{~T} \text {. } \\
\text { suckling ewes }\end{array}$ & $\begin{array}{l}\text { T. cc } \\
\text { abrifo }\end{array}$ & $\begin{array}{l}\text { iformis per da } \\
\text { per day. }\end{array}$ & & & & & \\
\hline
\end{tabular}

Samples of blood were analysed for total specific antibody and $\lg$ A specific antibody against the L3 stages of both $T$. circumcincta and T. colubriformis, by the methods of Xie et al. (2004) and for specific IgE by the method described by Huntley et al. (1998). In addition, interleukin 5 (IL5) was measured by indirect ELISA using the method developed and described by Else and Grencis (1991) and recommended for use in sheep by Doligalska et al. (1999).

\section{Necropsy}

The animals were stunned by captive bolt and the spinal cord and carotid artery and jugular veins severed immediately. The abdomen was opened along the central line and ligatures applied at the oesophageal junction with the abomasum, at the pyloris and in the small intestine $5 \mathrm{~m}$ distal to the pyloris and these tissues removed. Three samples $\left(2 \mathrm{~cm}^{2}\right)$ of abomasal wall from along the greater curvature and three samples of intestine taken $1 \mathrm{~m}$ from the pylorus were removed. One sample from each site was placed in each of liquid nitrogen, $5 \mathrm{ml}$ paraformaldehyde or $5 \mathrm{ml}$

Table 2 Composition ( $\mathrm{g} / \mathrm{kg}$ fresh weight) and analysis of feeds

\begin{tabular}{|c|c|c|c|}
\hline & $\begin{array}{l}\text { Low protein } \\
\text { pellets }\end{array}$ & $\begin{array}{l}\text { High proteir } \\
\text { pellets }\end{array}$ & n Hay \\
\hline Chaffed lucerne hay & 515 & 515 & \\
\hline Barley & 430 & 230 & \\
\hline Molasses & 50 & 50 & \\
\hline Fish meal & - & 200 & \\
\hline Mineral mix & 5 & 5 & \\
\hline Dry matter (DM) & 866 & 862 & 881 \\
\hline Digestible organic matter (DOMD \%) & 730 & 750 & 545 \\
\hline Crude protein (g/kg DM) & 176 & 287 & 104 \\
\hline Metabolisable energy (ME, MJ/kg DM) & 11.4 & 11.7 & 7.2 \\
\hline Metabolisable protein $(\mathrm{MP}, \mathrm{g} / \mathrm{kg} \mathrm{DM})^{\dagger}$ & 93 & 154 & 74 \\
\hline \multicolumn{4}{|c|}{ Estimated supply of ME and MP in mixed ration offered ( $2: 1$; conc:hay) } \\
\hline ME (MJ/kg DM) & 10 & 10.2 & \\
\hline $\mathrm{MP}(\mathrm{g} / \mathrm{kg} \mathrm{DM})^{\dagger}$ & 83 & 127 & \\
\hline
\end{tabular}

\footnotetext{
${ }^{\dagger}$ Estimated from AFRC (1993) assuming rumen outflow rate $(r)=0.08$
}

modified Bouin-picric acid solution. The former was transferred to $-20^{\circ} \mathrm{C}$ after 30 to $60 \mathrm{~min}$ and the latter two into $70 \%$ alcohol $(1.5 \mathrm{ml})$ after $6 \mathrm{~h}$ and then maintained at $4{ }^{\circ} \mathrm{C}$.

Abomasal and intestinal contents and washings were collected and the tissues digested in acidified pepsin solution (Herlich, 1956) to recover mature worms and immature stages (Robertson and Elliott, 1966). Worms were differentiated into developmental stages (third (L3), fourth (L4) and adult (L5)) based on the information of Threkeld (1934).

\section{Histology}

Excised abomasal tissues and fixed tissues were processed as described by Huntley et al. (2004). For the histochemical counting of mast cells, Bouins fixed sections were stained with toluidine blue at pH 0.5 (Enerback, 1966). Counts of globule leucocytes and eosinophils were made after staining 4\% paraformaldehyde-fixed tissue sections with carbol chromotrope (Lendrum, 1944), and were differentiated on morphological criteria. Stained cells were counted under a $\times 10$ eye piece containing a calibrated graticule and a $\times 25$ objective lens viewing an area of $0.08 \mathrm{~mm}^{2}$ and counts were made from 10 graticule fields made systematically from the lamina muscularis to the mucosal surface. The counts were expressed as mean numbers per $0.2 \mathrm{~mm}^{2}$.

\section{Statistical analysis}

Due to missing data resulting from scanning inaccuracies and loss of lambs at parturition (see Table 1) number of lambs reared was introduced as a treatment effect. Transformations were used on the data on the basis of residual plots. The actual transformations used are given in the appropriate captions of the tables and figures. The generalised linear model in Genstat (Lawes Agricultural Trust, 2002) was used for analysis of worm burdens and the residual maximum likelihood (REML) in Genstat for parameters with repeated observations in time and the covariance structure of these data accommodated. In the case of worm burdens analyses were carried out across the total population, using species and developmental 
Sykes, Xie, Stankiewicz, Huntley, Mackellar, Sedcole, McAnulty and Green

stages of the nematodes as fixed effects, and separately for each nematode species. The ratio of $L 3+L 4$ to total worm burden was also analysed separately for each species.

The experiment was carried out under the authority of the Committee of Ethics of Animal Experimentation of Lincoln University, New Zealand (certificate no. 803).

\section{Results}

At parturition inaccuracies in scanning of foetuses was detected and there were some losses of lambs, particularly twin lambs. The number of ewes that successfully reared lambs and the distributions of twin and single reared lambs are given in Table 1. Vaccinated sheep on the high protein diet reared a disproportionately small and their unvaccinated contemporaries a disproportionately large number of twin lambs.

Animals generally consumed all the feed offered. As a consequence estimated ME intake increased from about 11.3 MJME per day during week -8 relative to parturition through 14.5 MJME per day during week -5 and 20.4 MJME per day during week -2 . These were within $5 \%$ of the theoretical requirement for twin-bearing ewes of this body weight. MP intakes, calculated according to AFRC (1993), see Table 2, were 82 and $127 \mathrm{~g}$ MP per day during week -8 and 146 and $224 \mathrm{~g}$ MP per day during week -2 relative to parturition for LP and HP groups, respectively. During lactation LP and HP sheep generally consumed all the feed offered which was estimated to provide 30-35 MJME per day for both groups and 260 and $380 \mathrm{~g} \mathrm{MP}$ per day for those on the LP and HP diets, respectively.

\section{Ewe live weight}

The mean LWs of the ewes are given in Figure 1. There were significant interactions between time and litter size and effects of time $(P<0.01$ in both cases) reflecting increase in LW before lambing and losses during parturition and subsequently during lactation, particularly in ewes rearing more than one lamb. There were no effects of dietary protein supply or vaccinating infection.

\section{Ewe faecal egg count}

The changes in mean faecal egg count are given in Figure 2 . There was a significant dietary protein $x$ litter size $X$ time interaction $(P<0.01)$ and significant protein $\times$ time and litter size $\times$ time interactions $(P<0.001$ in both cases) due to the rise in FEC in all groups after parturition and larger increases in animals on the low protein diet and in multiple-rearing ewes. In particular the rise in FEC in single-rearing ewes on the high protein diet was delayed, compared with the other groups. There was also a highly significant time $\times$ vaccination treatment interaction $(P<0.001)$ as a consequence of lower FEC immediately after parturition in those ewes that received a vaccinating infection during late pregnancy.

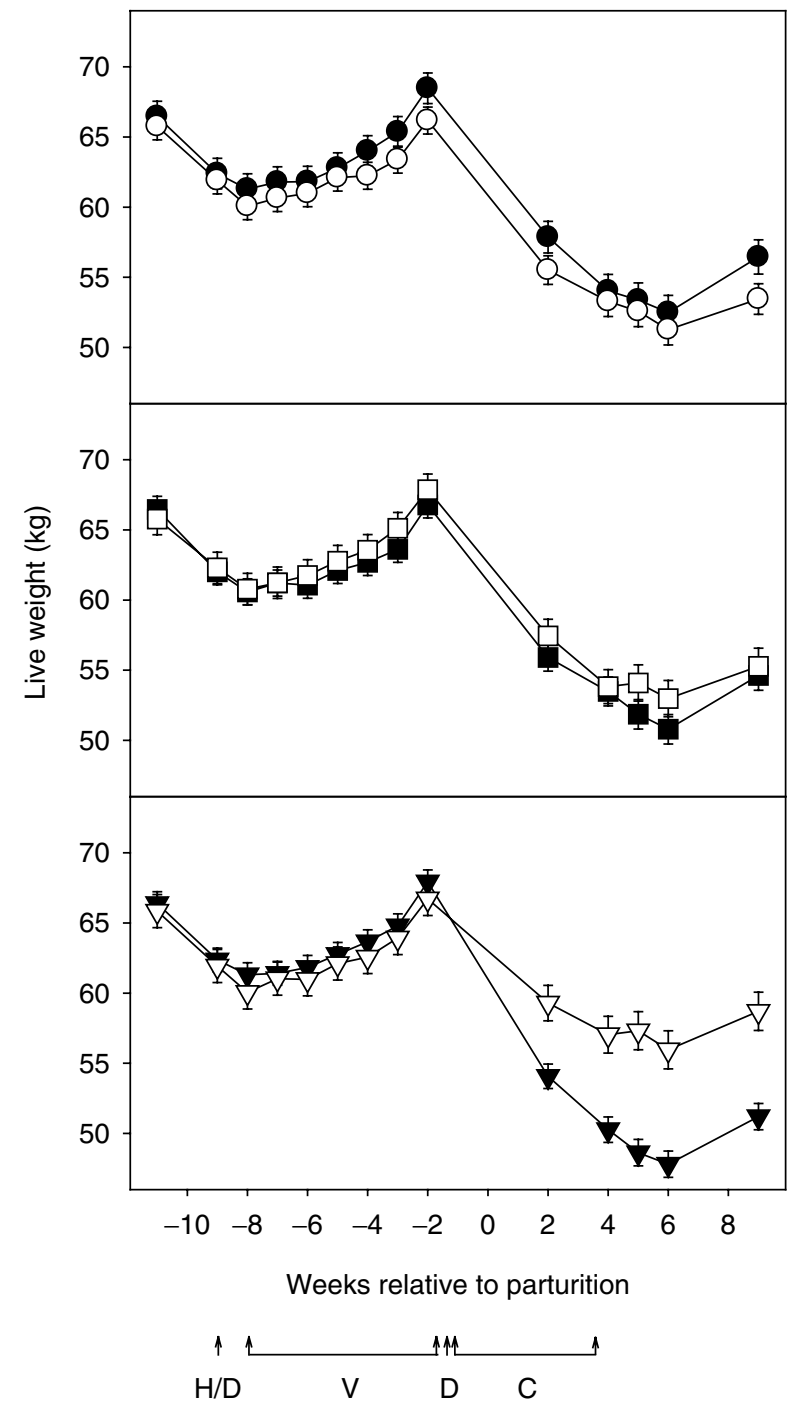

Figure 1 Live-weight changes in periparturient ewes infected with the nematodes $T$. circumcincta and T. colubriformis; effect of offering feed providing an estimated $130 \%(\bullet)$ or $80 \%(\bigcirc)$ of metabolisable protein requirement; effect of presence $(\square)$ or absence $(\square)$ of a vaccinating infection during mid-late pregnancy and effect of bearing and rearing multiple $(\boldsymbol{\nabla})$ or single $(\nabla)$ lambs. Note: $H / D$, housing and drench of all animals; $V$, vaccinating infection; $D$, drench of all animals; $C$, challenge of all animals.

\section{Worm burdens}

The mean numbers of $T$. circumcincta and $T$. colubriformis recovered from the groups slaughtered 1 and 3 weeks after parturition are given in Table 3. When analysed across nematode species there were interactions between species total and necropsy time $(P<0.001)$ and between numbers of nematodes in the different development stages with protein supply $(P<0.001)$, vaccination status $(P<0.01)$ and slaughter time $(P<0.001)$ and significant main effects of protein supply $(P<0.001)$, vaccinating infection $(P<0.01)$, number of lambs reared $(P<0.001)$ and nematode species $(P<0.01)$. Analyses within nematode species showed significant effects of dietary protein supply on the numbers of worms of $T$. circumcincta $(P<0.01)$ and of $T$. colubriformis $(P<0.001)$ and a 

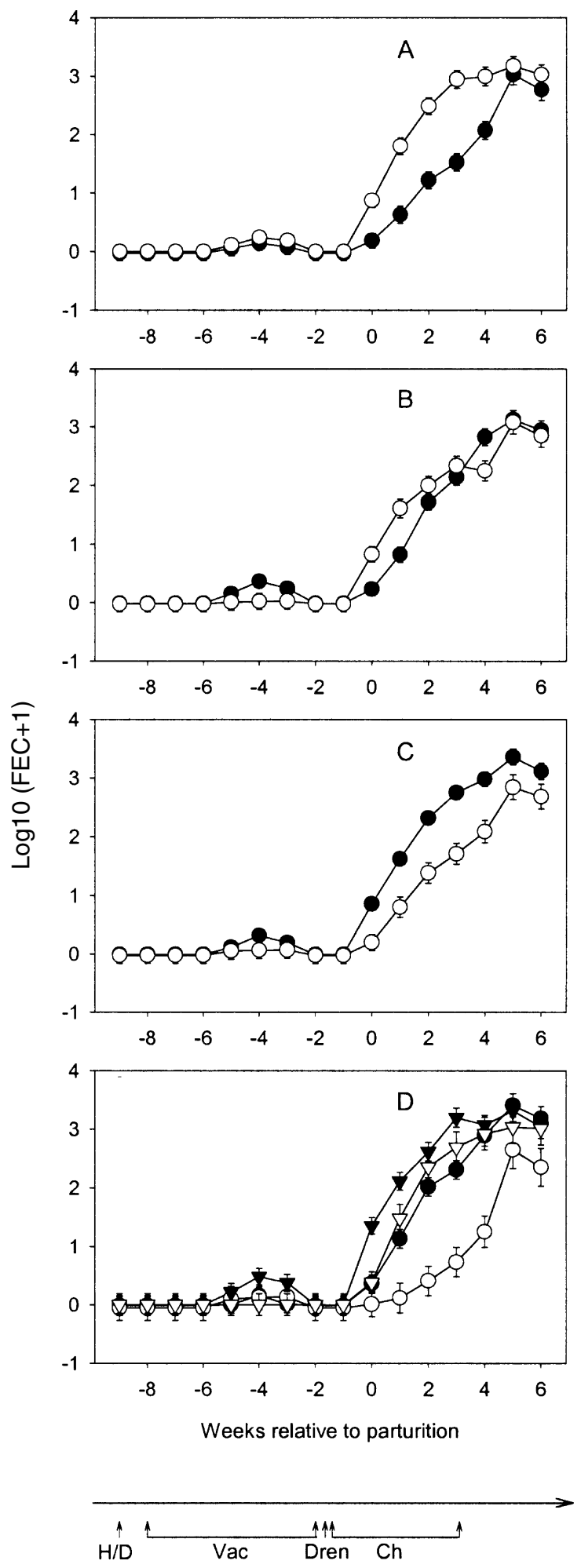

Figure 2 Mean faecal egg count $(\log 10($ count +1$))$ of periparturient ewes infected with the nematodes $T$. circumcincta and $T$. colubriformis: (a) effect of offering feed providing an estimated $130 \%(\bullet)$ or $80 \%(\bigcirc)$ of metabolisable protein requirement; (b) effect of presence (0) or absence $(O)$ of a vaccinating infection; (c) effect of rearing single- $(\nabla)$ or twin- ( $\mathbf{\nabla})$ lambs; (d) interaction of rearing status and MP supply- $(\mathbf{0}, 0$ $H P ; \nabla, \nabla, L P)$, single- and twin-rearing represented in open and closed symbols, respectively. Note: $H / D$, housing and drench of all animals; $V$, vaccinating infection; $D$, drench of all animals; $C$, challenge of all animals. significant effect of litter size on numbers of the latter $(P<0.01)$ but not the former nematode. Worm numbers were reduced by the vaccinating infection $(P<0.05$ for both nematodes). Worm numbers of $T$. colubriformis increased between the first and second necropsies $(P<0.05)$ but those of $T$. circumcincta were stable. There was, however, a highly significant $(P<0.001)$ reduction in the proportion of the population of $T$. circumcincta in the developing stages $(\mathrm{L} 3+\mathrm{L} 4)$ at the second necropsy, which reflected a reduction (proportionate 0.51 ) in $\mathrm{L} 3+\mathrm{L} 4$ numbers and an increase (proportionate 1.6) in adult numbers at the second necropsy. By comparison the trend for reduction $(P>0.05)$ in the $\mathrm{L} 3+\mathrm{L} 4$ contribution to total worm burden of $T$ colubriformis at the second necropsy was the resultant of large increases in both $\mathrm{L} 3+\mathrm{L} 4$ (proportionate 2.1) and adult (proportionate 6.4) worms. Only the effects of protein supply and vaccinating infection on the proportion of developing stages of $T$. circumcincta were statistically significant $(P<0.04$ and 0.06 , respectively).

\section{Serum total antibody}

The changes in serum total antibody against $T$. circumcincta and $T$. colubriformis are given in Figure 3 . For antibodies to both parasites there was a significant vaccinating challenge $\times$ time interaction $(P<0.001$ in both cases) reflecting a decline in antibody titres during pregnancy in unvaccinated sheep. Significant time effects for antibodies to both nematodes $(P<0.001$ in both cases) were a reflection of values that peaked at parturition followed by an immediate decline and subsequent recovery.

\section{Serum $\lg A$}

The parasite L3-specific serum IgA titres are given in Figure 4 . For serum IgA against $T$. circumcincta there were vaccination $\times$ time $(P<0.001)$ and litter size $\times$ time $(P<0.05)$ interactions reflecting lower levels in unvaccinated sheep during pregnancy and after parturition and lower levels in singlethan in multiple-bearing and rearing sheep.

For $T$. colubriformis there were significant vaccination $\times$ time interactions and effect of litter size $(P<0.001$ in both cases) but no litter size $\times$ time effects. For IgA antibodies to both nematodes significant effects of time $(P<0.01$ in both cases) was due to increasing titres until the week before parturition and subsequent stabilisation. There was no effect of dietary protein supply on IgA titres to L3 larvae of either nematode.

\section{Serum $\lg E$}

The changes in serum IgE against $T$. circumcincta and $T$. colubriformis are given in Figure 5 . There were vaccination $\times$ time interactions $(P<0.001$ and $P<0.01$ for $T$. circumcincta and $T$. colubriformis, respectively), the result of lower values in unvaccinated sheep, particularly during pregnancy and significant time effects $(P<0.001$ in both cases). The latter reflected a trend for increase in titres during pregnancy and decline during lactating, 
Sykes, Xie, Stankiewicz, Huntley, Mackellar, Sedcole, McAnulty and Green

Table 3 Main effects of dietary protein, vaccination, number of lambs reared and time of slaughter after parturition on fourth root transformed total worm burdens and ratio of 3rd and 4th stage larvae to total worm numbers of T. circumcincta and T. colubriformis in periparturient ewes (back-transformed means of total burdens are given in parentheses) (number of ewes in each group $=20$ )

\begin{tabular}{|c|c|c|c|c|c|c|c|c|c|}
\hline & \multicolumn{2}{|c|}{ Protein } & \multicolumn{2}{|c|}{ Vaccination } & \multicolumn{2}{|c|}{ Litter size } & \multicolumn{2}{|c|}{ Slaughter time } & \multirow[b]{2}{*}{ Average s.e. } \\
\hline & High & Low & Vaccinated & Un-vaccinated & Multiple & Single & Week 1 & Week 3 & \\
\hline T. circumcincta & $7.97(4030)$ & $11.46(17230)$ & $9.06(6730)$ & $10.37(11560)$ & $10.50(12160)$ & $8.92(6340)$ & $9.74(9010)$ & $9.68(8780)$ & 0.79 \\
\hline $\begin{array}{l}\text { L3 + L4/total } \\
\text { worms }\end{array}$ & 0.52 & 0.39 & 0.50 & 0.39 & 0.45 & 0.46 & 0.59 & 0.31 & 0.068 \\
\hline T. colubriformis & $6.66(1960)$ & $9.29(7460)$ & $7.17(2640)$ & $8.78(5950)$ & $9.26(7340)$ & $6.69(2010)$ & $6.54(1830)$ & $9.41(7830)$ & 0.96 \\
\hline $\begin{array}{l}\text { L3 + L4/total } \\
\text { worms }\end{array}$ & 0.59 & 0.32 & 0.54 & 0.38 & 0.43 & 0.49 & 0.57 & 0.35 & 0.112 \\
\hline
\end{tabular}

commencing just before parturition. The time effect was more marked for IgE against $T$. circumcincta. There was a protein $\times$ time interaction for $T$. colubriformis $(P<0.01)$ but not for $T$. circumcincta, though in both cases titres tended to be lower in high protein groups during lactation.
Serum interleukin 5

There was a significant effect of time $(P<0.001)$ due to the depression of concentrations around parturition. Concentrations $(\log 10 \mathrm{pg} / \mathrm{ml})$ tended upwards during pregnancy from 1.9 to 2.1, 2 weeks before parturition, but fell to 1.7 in the 3 weeks around parturition and then rose during

A

B

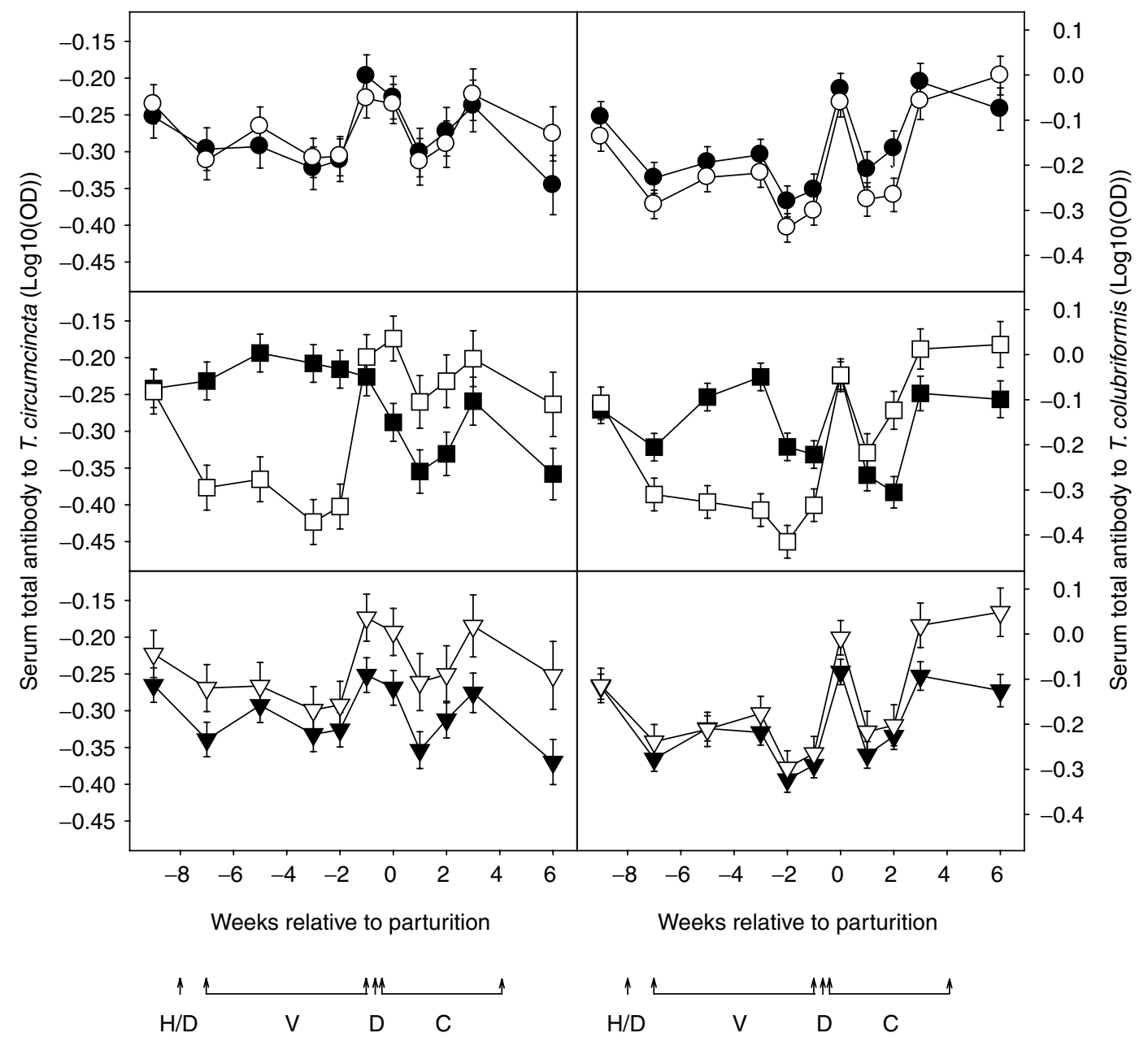

Figure 3 Changes in serum total antibody against (a) T. circumcincta and (b) T. colubriformis in periparturient ewes; effect of offering feed providing an estimated $130 \%(\bullet)$ or $80 \%(\bigcirc)$ of MP requirement; effect of presence $(\square)$ or absence $(\square)$ of a vaccinating infection during mid-late pregnancy and effect of bearing and rearing multiple $(\boldsymbol{\nabla})$ or single $(\nabla)$ lambs. Note: H/D, housing and drench of all animals; V, vaccinating infection; $D$, drench of all animals; $C$, challenge of all animals. 
A

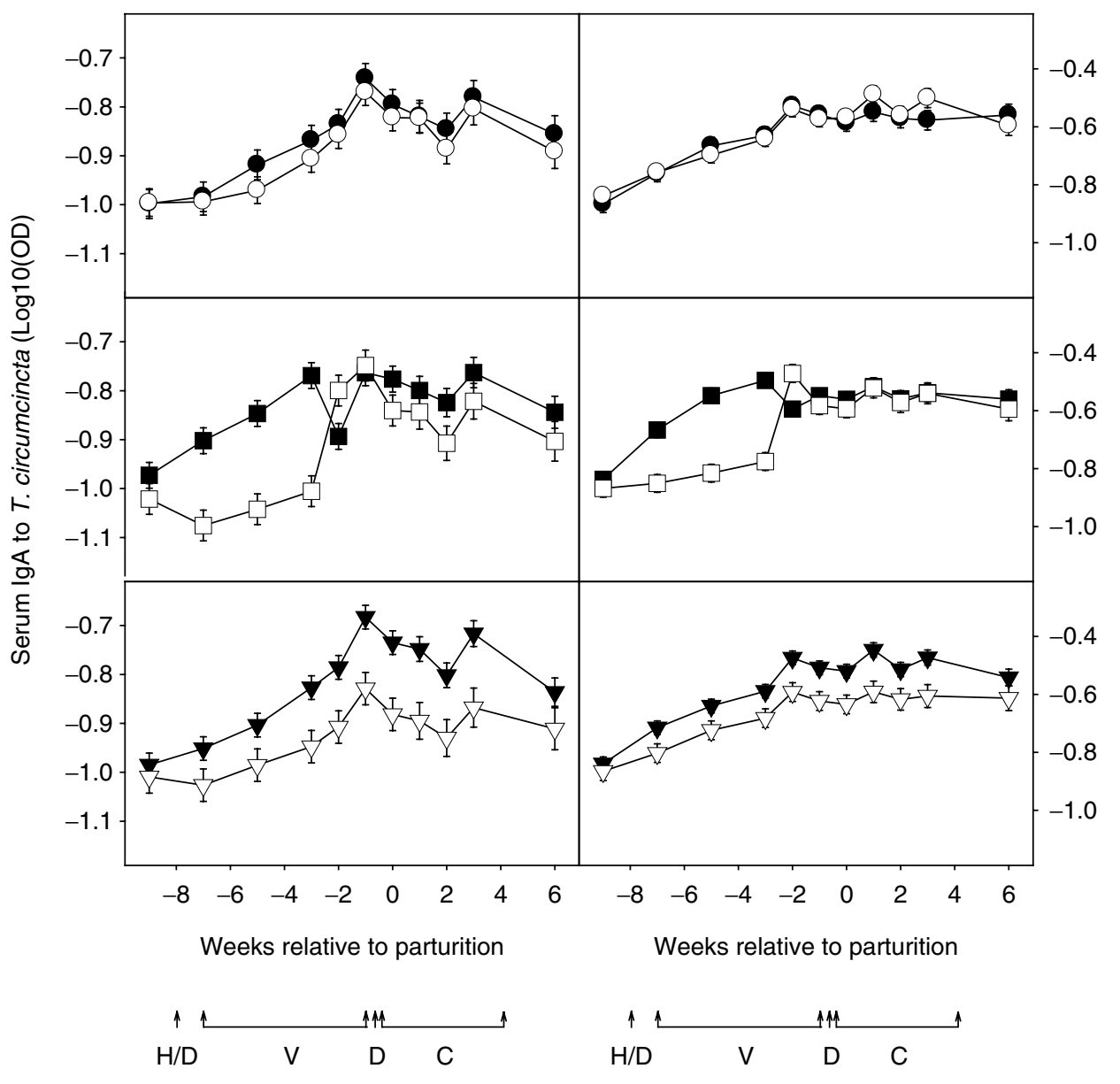

Figure 4 Changes in serum specific IgA against (a) T. circumcincta and (b) T. colubriformis in periparturient ewes; main effect of offering feed with estimated $130 \%(\bullet)$ or $80 \%(O)$ of MP requirement; effect of presence $(\square)$ or absence $(\square)$ of a vaccinating infection during mid-late pregnancy and effect of bearing and rearing multiple $(\boldsymbol{\nabla})$ or single $(\nabla)$ lambs. Note: $H / D$, housing and drench of all animals; $V$, vaccinating infection; $D$, drench of all animals; $C$, challenge of all animals.

lactation. A protein $\times$ time interaction $(P<0.05)$ reflected lower concentrations during lactation in animals offered the high protein supply.

\section{Mucosal inflammatory cells}

The numbers of inflammatory cells in abomasal and intestinal lamina propria tissue at the two slaughter times are given in Table 4. The major finding was of significant between animal variation. Vaccination resulted in greater numbers of mucosal mast cells (MMC) in both tissues and a highly significant increase in globule leucocyte $(\mathrm{GL})$ numbers in abomasal tissue but not in intestinal tissue. In the latter tissue there was a trend $(P>0.05)$ for increase in eosinophil (EOS) numbers but in abomasal tissue a significant reduction though at much lower cell numbers. Increased MP supply was associated with an increase in MMC in both tissues, significantly so in intestinal tissue, with no change in EOS or GL in abomasal tissue, but with a trend for reduction in EOS $(P>0.05)$ and increase $(P<0.05)$ in GL cell numbers in intestinal tissue. In abomasal tissue $G L$ numbers increased between weeks 1 and 3 after parturition whereas in intestinal tissue GL cell numbers decreased during this time. Interactions between treatments were not observed for EOS numbers or for numbers of MMC in intestinal tissue. In abomasal tissue there was a trend for a vaccination $X$ necropsy time interaction $(P<0.06)$ reflecting greater difference in numbers in vaccinated sheep at the first than at the second necropsy. For GL in both tissues there were several weak interactions $(P<0.06$ to 0.1$)$; (a) a trend for the difference in cell numbers between vaccinated and unvaccinated sheep to be greater at the first than at the second necropsy; (b) in intestinal tissue for lack of vaccinating infection to have greater effect on cell numbers at the lower than at the high protein supply; (c) in abomasal tissue, for cell numbers to be reduced by the low protein supply or by lack of vaccinating challenge to a greater degree in twin-rearing than in single-rearing ewes.

Negative correlations were observed between numbers of $T$. colubriformis and density of MMC and GL in intestinal tissue $(-0.65$ and $-0.61 ; P<0.001$ in both cases) and between $T$. circumcincta worm burdens and $M M C$ in abomasal tissue $(-0.43 ; P<0.01)$ when data from the treatment groups were combined. A positive correlation 
A

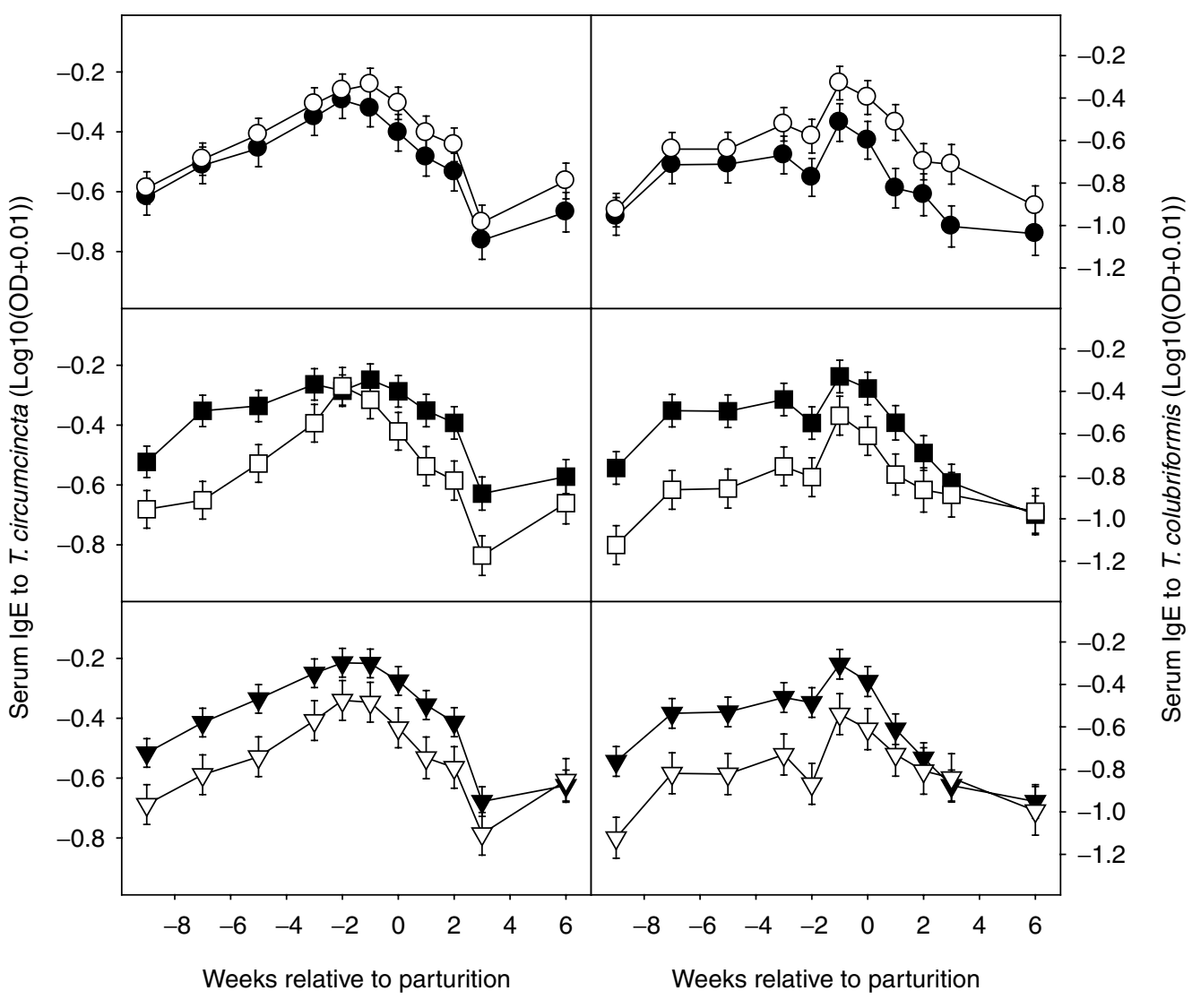

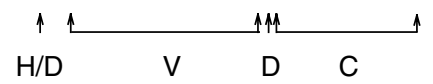

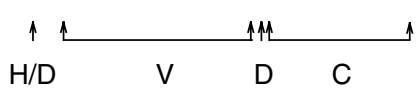

Figure 5 Changes in serum specific IgE against (a) T. circumcincta and (b) T. colubriformis in periparturient ewes; main effect of offering feed with estimated $130 \%(\mathbf{O})$ or $80 \%(O)$ of MP requirement; effect of presence $(\boldsymbol{\square})$ or absence $(\square)$ of a vaccinating infection during mid-late pregnancy and effect of bearing and rearing multiple $(\boldsymbol{\nabla})$ or single $(\nabla)$ lambs. Note: H/D, housing and drench of all animals; V, vaccinating infection; $D$, drench of all animals; C, challenge of all animals.

was also observed between abomasal worm burdens and EOS numbers in abomasal mucosa $(0.37 ; \quad P<0.02)$. Relationships were not observed between eosinophil numbers in intestinal tissue and burdens of $T$. colubriformis or between worm burdens and numbers of $\mathrm{GL}$ in the abomasums.

\section{Discussion}

The importance of dietary protein supply for the ability of the ewe to maintain protection against nematode parasites in the period around parturition is now well established as is the influence of numbers of lambs reared (Donaldson et al. (1998 and 2001), Houdijk et al. (2000, 2001a and b

Table 4 Main effects of dietary protein, vaccination, litter size status and time of slaughter after parturition on numbers of local inflammatory cells $\left(\log 10(n+1)\right.$ transformed data with back-transformed means in parentheses in abomasal and intestinal mucosa from periparturient ewes ${ }^{\dagger}$

\begin{tabular}{|c|c|c|c|c|c|c|c|c|c|}
\hline & \multicolumn{2}{|c|}{ Protein } & \multicolumn{2}{|c|}{ Vaccination } & \multicolumn{2}{|c|}{ Litter size } & \multicolumn{2}{|c|}{ Week after parturition } & \multirow[b]{2}{*}{ Average s.e. } \\
\hline & High & Low & Vaccinated & Un-vaccinated & Multiple & Single & 1 & 3 & \\
\hline Abomasal EOS & $0.173(1.5)$ & $0.477(3.00)$ & $0.064(1.15)^{*}$ & $0.586(3.85)$ & $0.187(1.54)$ & $0.462(3.0)$ & $0.199(1.58)$ & $0.450(2.89)$ & 0.207 \\
\hline Abomasal MMC & $1.682(48.1)$ & $1.443(27.7)$ & $1.689(48.8)^{*}$ & $1.436(27.3)$ & 1.598 (39.6) & 1.527 (33.6) & $1.634(43.1)$ & $1.491(30.9)$ & 0.083 \\
\hline Abomasal GL & $0.933(8.5)$ & $1.021(10.5)$ & $1.348(22.3)^{* * *}$ & $0.606(4.04)$ & $0.868(7.38)$ & $1.085(12.2)$ & $0.632(4.29)^{*}$ & $1.322(21.0)$ & 0.171 \\
\hline Intestinal EOS & $1.356(22.7)$ & $1.512(32.5)$ & $1.289(19.5)$ & $1.580(38.0)$ & $1.401(25.2)$ & $1.467(29.3)$ & $1.419(26.2)$ & $1.450(21.0)$ & 0.111 \\
\hline Intestinal MMC & $1.694(49.4)^{*}$ & 1.526 (33.6) & $1.684(48.3)^{*}$ & $1.535(34.3)$ & $1.575(37.6)$ & $1.644(44.1)$ & $1.700(50.1)^{*}$ & $1.519(28.1)$ & 0.073 \\
\hline Intestinal GL & $0.560(3.63)^{*}$ & $0.012(1.02)$ & $0.292(1.96)$ & $0.279(1.90)$ & $0.018(1.04)^{* *}$ & $0.589(3.88)$ & $0.613(4.10)$ ** & $0.041(1.10)$ & 0.205 \\
\hline
\end{tabular}

${ }^{\dagger}$ EOS, eosinophil; GL, globule leukocytes; MMC, mucosal mast cell. ${ }^{*} P<0.05 ;{ }^{* *} P<0.01 ;{ }^{* * *} P<0.001$. 
and 2003) and Kahn et al. (2003)). The present data add further weight to the concept that nutrient scarcity per se, reflecting competing demands of lactation and the immune system for nutrients, is critical. Effects of vaccinating infection, though measurable in a halving of worm burdens of both nematode species 7 days after lambing, were small and transitory in their effect on FEC in comparison with the effect of protein supply or numbers of lambs reared. In this context the observations of Houdijk et al. (2003) of greater sensitivity of the immune system than milk synthesis to marginal protein supply is telling.

FEC, however, is the resultant of numbers of mature worms and their fecundity each of which may be the subject of limitation by the host immune response. While the experimental design did not allow analysis of these components the serial necropsy approach provided evidence that the direction of response to the two nematode populations to increased host MP supply, vaccinating infection and lactational demand were similar. In a temporal sense, however, there were differences in worm population dynamics (Table 3). Whereas the population of $T$. circumcincta was stable between weeks 1 and 3 after lambing, and there was evidence for limitation of development of incoming larvae, that of $T$. colubriformis was increasing. This inability to control the population of the intestinal nematode $T$. colubriformis may have been responsible for the trend for FEC to continue to increase and for differences in FEC between treatment groups to disappear as lactation progressed. Other comparable studies but using single-species infections with the abomasal nematode $T$. circumcincta have generally observed a decrease in FEC after about 3 to 4 weeks of lactation especially in protein supplemented groups (Houdijk et al., 2003 and 2005), consistent with observations of restoration of ability limit development of larvae of $T$. circumcincta within 2 to 4 weeks of parturition in well fed sheep (McAnulty et al., 2001).

The pattern of changes in cells of the immune armoury in the gastro-intestinal mucosa was consistent with the general direction of nematode population responses to treatments but there was evidence to suggest that the precise association between the host immune system and the nematode populations for the two nematodes may differ. The typical pattern of response of the immune armoury under larval challenge has been described by Balic et al. (2000). In animals with no previous exposure a nonspecific recruitment in mucosal tissues of eosinophils and production of $\lg \mathrm{A}$ antibody is followed by increases in MMC and their de-granulated cell remnant, GL (Huntley et al., 1984; Pfeffer et al., 1996). Subsequently, EOS recruitment to tissue and antibody production diminish, a pattern which has been observed in peripheral EOS numbers (Kimambo et al., 1988) and IgA antibodies (Cripps and Steel, 1978; Henderson and Stear, 2006). Balic et al. (2000) interpreted changes in EOS numbers as indicating recruitment to mucosal tissue until the components of the mature protective immune armoury are able to exclude larvae from mucosal tissue. Circulating concentrations of antibodies have been shown to be highly correlated with rates of antibody production (Cripps and Steel, 1978) though the sensitivity of peripheral $\lg A$ to small changes in production in mucosal tissue is unclear (Sinski et al., 1995; Henderson and Stear, 2006). The ubiquitous increase in IgA in peripheral circulation during the acquisition of immunity in naïve animals and its subsequent decline (Cripps and Steel, 1978; Henderson and Stear, 2006) and the lack of peripheral response in animals with established immunity (Greer et al., 2005) suggests that, like eosinophils, its rate of production in mucosal tissues, and therefore appearance in circulation, may reflect the extent of larval penetration of the tissue determined by the effectiveness of the mature mucosal-cell based immune response. The present sheep would have been expected to have had an established immunity to the nematode species used as a consequence of an inevitable exposure to larvae of these nematodes which are endemic in the farm environment in which they had been reared. Had withdrawal from the antigenic stimulation of the non-vaccinated sheep led to a reduction in MMC/GL (Huntley et al., 1992) we could have anticipated a greater recruitment of eosinophils and IgA production. Conversely, we could have expected a response dominated by higher numbers of MMC/GL and fewer eosinophils in vaccinated sheep, particularly on the high protein diet and a stronger shift towards greater numbers of $\mathrm{MMC} / \mathrm{GLs}$ in the latter sheep between weeks 1 and 3 with more rapid re-establishment of immunity. The findings of positive correlation between EOS numbers and worm burdens in abomasal tissue, negative correlations between MMC and worm burdens in both abomasal and intestinal tissues and negative correlations between $\mathrm{GL}$ and worm burdens in intestinal tissue are consistent with this interpretation.

The trend for lower EOS numbers in the abomasal and intestinal mucosa of HP and vaccinated animals (Table 4) suggests a greater ability to exclude incoming larvae from tissues which is consistent with the lower worm numbers in these groups and the findings of Donaldson et al. (2001) that increased protein supply was associated with lower establishment of larvae of T. circumcincta. Houdijk et al. (2003) observed a similar sensitivity of abomasal eosinophil numbers to MP supply 3 weeks after lambing in Teladorsagia circumcinctainfected sheep but only at much lower MP supply ( $180 \mathrm{~g} /$ day) than the range (220 to $380 \mathrm{~g} /$ day) used in the present study. The trend for greater EOS numbers in abomasal tissue and similar numbers in intestinal tissue from single-rearing ewes is, however, inconsistent with their lower worm burdens than twin-rearing ewes.

MMC numbers, as expected (Balic et al., 2000), were lower in unvaccinated sheep and tended to be lower in sheep on the LP diet, especially in the intestine. The actual numbers were comparable with the 30 to 40 cells per $0.2 \mathrm{~mm}^{2}$ observed by Houdijk et al. (2005) in lactating sheep. These authors, however, observed a marked depression from the 80 to 120 cells per $0.2 \mathrm{~mm}^{2}$ in non-pregnant sheep to less than 10 cells per $0.1 \mathrm{~mm}^{2}$ in the period immediately around 
parturition followed by a rise during lactation. Thus it would appear that MMC numbers are inherently diminished by factors associated with the reproductive process. Our data suggest that the extent of the reduction is influenced by antigenic experience and protein nutrition. In this respect the observation, in the present work, of significant reduction in interleukin 5 in the period 2 weeks before to a week after parturition may be relevant. It is, we believe, the first evidence that signaling through cytokines in the sheep immune system may be disturbed around parturition and deserves further study in relation to migration and functionality of cells of the local immune response. The technique used in this study was the best available at the time of the experimentation; the conserved nature of IL-5 was considered sufficient to ensure a high level of cross reactivity as discussed by Doligalska et al. (1999). Clearly, these findings suggest it should be further investigated using specific monoclonal antibodies against ovine IL-5.

The increase in GL numbers in the intestine as a result of the HP diet and single-rearing suggests changes in MMC de-granulation also consistent with enhanced immune capability. Though these specific trends were not shown in abomasal tissue, vaccination was associated with much greater numbers of $G L$ in this tissue. In fact, the total numbers of GL in abomasal and intestinal tissue were very different, averaging 13 and less than 2 , respectively the former being much greater than the 2 to 4 cells per $\mathrm{mm}^{2}$ observed by Houdijk et al. (2003). If GL are de-granulated remnants of discharged MMC (Huntley et al., 1992) the present data suggest a more rapid turnover of MMC in abomasal than in intestinal tissue.

When viewed together and from a standpoint of immune system ontogony, the association of low EOS numbers with high GL numbers in abomasal tissue and of high EOS numbers with low GL in intestinal tissue does suggest that the host ability to regulate worm populations was more advanced in abomasal tissue, which is consistent with the worm population dynamics discussed earlier. This hypothesis involves an as yet unvalidated assumption that the pattern of involvement of cells of the immune response is identical in the two tissues and Balic et al. (2000) cautioned that 'it may well be that present methods for quantifying MMC/GL numbers may not accurately reflect their number or activation status.' The present appears to be the first study in which cells have been measured in the two sites simultaneously and does suggest there may be differences in mechanism or timing of immune responses. The broadly similar direction of changes in EOS, MMC and GL as a consequence of vaccination and increased protein supply suggests that the effect of dietary protein in enhancing protection operates through enhancing retention or recruitment of cells associated with the local cellular development in line with the findings of Coop et al. (1995) that the ability to generate mast cell derived protease activity during vaccinating infection of immunologically naïve animals is enhanced by dietary protein supply.
None of the serum antibody isotypes was affected by dietary protein supply which perhaps adds weight to the hypothesis that the effect of enhanced protein supply in the peri-partum period is primarily through effect on local mucosal cell populations and their activity.

Total antibody titres were only maintained by a current larval intake, titres declining in unvaccinated sheep during pregnancy but were very rapidly restored during the last 2 weeks of pregnancy on restoration of larval challenge. This pattern clearly refutes a putative immuno-suppressive effect of pregnancy on antibody production as previously suggested by Lloyd (1983). The subsequent reduction in titres 2 weeks after lambing could reflect suppression around parturition but, perhaps more plausibly, the active transfer into colostrum (Brambell, 1970; Butler et al., 1972; Sasaki et al., 1976).

IgA levels increased significantly during pregnancy only in sheep experiencing vaccinating infections but, like total antibody, increased rapidly on commencement of challenge infections of unvaccinated sheep, suggesting increase in production of the antibody in mucosal tissue during late pregnancy. A similar rise in titres observed in ewes around parturition during infection with $T$. circumcincta (Jeffcoate et al., 1992) was attributed to either 'a general increase in IgA in preparation for lactation... or to increased antigenic stimulation caused by the presence of greater numbers of establishing and, or, developing worms at this time'. The latter interpretation seems plausible in view of the fact that elevation of peripheral $\lg A$ titres, like eosinophilia, appears to be a feature only of the acquisition phase of the immune response Greer et al. (2005). The fact that IgA levels increased in the vaccinated sheep as pregnancy advanced, and were greater in multiple- than in singlebearing and rearing ewes during late pregnancy and early lactation despite an anticipated greater transfer to milk, does perhaps support the hypothesis of increased antigenic stimulation as a consequence of relaxation of cell mediated immunity during pregnancy (Monterroso and Hansen, 1993; Roberts et al., 1996; Raghupathy, 1997; Miyaura and Iwata, 2002) as the nutritional demands of reproduction increased. The occurrence of eggs in the faeces of LP sheep during the later stages of the vaccinating challenge (Figure 2) and the low numbers of MMC observed in periparturient compared with non-pregnant sheep by Houdijk et al. (2005) also support this conclusion.

Although $\lg E$ is considered to be one of the important components of the protective mechanism in the gastric mucosa (Miller, 1984) concentrations in peripheral circulation were more related to the reproductive cycle than to larval challenge or nutritional status, a pattern observed by Houdijk et al. (2005) and observed previously in other species (Piccinni et al., 1995; Roberts et al., 1996; Miyaura and Iwata, 2002).

\section{Conclusions}

These findings provide further evidence that the ability to limit nematode worm populations in the peri-partum period 
in the breeding ewe is susceptible to dietary protein supply, and that responses in worm establishment can be anticipated at intakes in the range $250-374 \mathrm{~g} \mathrm{MP} / \mathrm{d}$. In addition, withdrawal from antigenic stimulation prior to lambing, as a result of husbandry practices, could have effect on ability to regulate worm populations but is probably of much less significance for FEC than protein nutrition or numbers of lambs suckled. Retention and recruitment of cells of the mucosal immune response mucosal mast cells and globule leucocytes - are dependent on continuous larval challenge and dietary protein supply and may explain the mechanism of effect of dietary protein supply on resistance to nematode infection.

\section{Acknowledgements}

The skilled technical assistance of C.M. Logan, M. Ridgway and $\mathrm{H}$. Howden. This project was funded by Meat NZ. J. Huntley and A. McKellar are supported by the Scottish Executive, Environment and Rural Affairs Department.

\section{References}

Agricultural and Food Research Council 1993. Energy and protein requirements of ruminants. An advisory manual prepared by the AFRC technical committee on responses to nutrients. $C A B$ International, Wallingford.

Balic A, Bowles VM and Meeusen ENT 2000. The immunobiology of gastrointestinal nematode infections in ruminants. Advances in Parasitology 45, 182-241.

Brambell FWR 1970. The transmission of passive immunity from mother to young. North-Holland Publishing, Amsterdam.

Butler JE, Kiddy CA, Pierce CS and Rock CA 1972. Quantitative changes associated with calving in the levels of bovine immunoglobulins in selected body fluids. I. Changes in the levels of $\operatorname{lgA}, \operatorname{lgG}_{1}$ and total protein. Canadian Journal of Comparative Medicine 36, 234-242.

Coop RL, Huntley JF and Smith WD 1995. Effect of dietary protein supplementation on the development of immunity to Ostertagia circumcincta in growing lambs. Research in Veterinary Science 59, 24-29.

Cripps AW and Steel JW 1978. Immunoglobulin metabolism in sheep infected with the small intestinal nematode Trichostrongylus colubriformis. Australian Journal of Experimental Biology and Medical Science 56, 181-194.

Doligalska M, Moskwa B and Stear MJ 1999. Relationships among peripheral eosinophilia, eosinophil peroxidase activity, interleukin-5 concentration and faecal nematode egg count during natural, mixed gastrointestinal nematode infection. Veterinary Immunology Immunopathology 70, 299-308.

Donaldson J, Van Houtert MJF and Sykes AR 1998. The effect of nutrition on the periparturient parasite status of mature ewes. Animal Science 67, 523-533.

Donaldson J, Van Houtert MJF and Sykes AR 2001. The effect of dietary fishmeal supplementation on parasite burdens of periparturient sheep. Animal Science 72, 199-205.

Else KJ and Grencis RK 1991. Cellular immune responses to the nematode parasite Trichuris muris I. Differential cytokine production during acute or chronic infection. Immunology 72, 508-513.

Enerback L 1966. Mast cells in rat gastrointestinal mucosa. IIV. Dye binding and metachromatic properties. Acta Pathologica Microbiologica et Immunologica Scandinavica 66, 303-312.

Familton AS and McAnulty RW 1997. Life cycles and development of nematode parasites of ruminants. In Sustainable control of internal parasites in ruminants (ed. GK Barrell), Animal Industries Workshop pp. 69-79. Lincoln University Press, Canterbury, New Zealand.

Greer AW, Stankiewicz M, Jay NP, McAnulty RW and Sykes AR 2005. The effect of concurrent corticosteroid-induced immuno-suppression and infection with the intestinal parasite Trichostrongylus colubriformis on feed intake and utilisation in both immunologically naive and competent sheep. Animal Science 80, 89-99.
Henderson NG and Stear MJ 2006. Eosinophil and IgA responses in sheep infected with Teladorsagia circumcincta. Veterinary Immunology and Immunopathology 112, 62-66.

Herlich $\mathrm{H}$ 1956. A digestion method for post mortem recovery of nematodes from ruminants. Proceedings of the Helminthology Society of Washington 23 , 102-103.

Houdijk JGM, Kyriazakis I, Coop RL and Jackson F 2001a. The expression of immunity to Teladorsagia circumcincta in ewes and its relationship to protein nutrition depend on body protein reserves. Parasitology 122, 661-672.

Houdijk JGM, Kyriazakis I, Jackson F and Coop RL 2001b. The relationship between protein nutrition, reproductive effort and breakdown in immunity to Teladorsagia circumcincta in perparturient ewes. Animal Science 72, 595-606.

Houdijk JGM, Kyriazakis I, Jackson F, Huntley JF and Coop RL 2000b. Can an increased intake of metabolizable protein affect the peri-parturient relaxation in immunity against Teladorsagia circumcincta in sheep? Veterinary Parasitology $91,43-62$.

Houdijk JGM, Kyriazakis I, Jackson F, Huntley JF and Coop RL 2005. Effects of protein supply and reproductive status on local and systemic immune responses to Teladorsagia circumcincta in sheep. Veterinary Parasitology 129, 105-117.

Houdijk JGM, Kyriazakis I, Jackson F, Huntley JF and Coop RL 2003. Is the allocation of metabolisable protein prioritised to milk production rather than to immune functions in Teladorsagia circumcincta - infected lactating ewes. International Journal of Parasitology 33, 327-338.

Huntley JF, Jackson F, Coop RL, Macaldowie C, Houdijk JGM, Familton AS, Xie $\mathrm{HL}$, Stankiewicz M and Sykes AR 2004. The sequential analysis of local inflammatory cells during abomasal nematode infection in peri-parturient sheep. Veterinary Immunology and Immunopathology 97, 163-176.

Huntley JF, Newlands GF, Jackson F and Miller HR 1992. The influence of challenge dose, duration of immunity, or steroid treatment on mucosal mast cells and on the distribution of sheep mast cell proteinase in Haemaonchusinfected sheep. Parasite Immunology 20, 565-571.

Huntley JF, Newlands GFG and Miller HRP 1984. The isolation and characterisation of globule leucocytes: their derivation from mucosal mast cells in parasitized sheep. Parasite Immunology 6, 371-390.

Huntley JF, Schallig HDFH, Kooyman FNJ, McKellar P, Millership J and Smith WD 1998. IgE responses in the serum and gastric lymph of sheep infected with Teladorsagia circumcincta. Parasite Immunology 20, 163-168.

Jeffcoate IA, Wedrychowicz H, Fishwick G, Dunlop EM, Duncan JM and Holmes PH 1992. Pathophysiology of the peri-parturient egg rise in sheep: a possible role for IgA. Research in Veterinary Science 53, 212-218.

Kahn LP, Knox MR, Walkden-Brown SW and Lea JM 2003. Regulation of the resistance to nematode parasites of single- and twin-bearing Merino ewes through nutrition and genetic selection. Veterinary Parasitology 114, 15-31.

Kimambo AE, MacRae JC, Walker A, Watt CF and Coop RL 1988. Effect of prolonged subclinical infection with Trichostrongylus colubriformis on the performance and nitrogen metabolism of growing lambs. Veterinary Parasitology 28, 191-203.

Lloyd S 1983. Effect of pregnancy and lactation upon infection. Veterinary Immunology and Immunopathology 4, 153-176.

Lawes Agricultural Trust 2002. GENSTAT, release 6.1. VSN International Ltd, Oxford, UK.

Lendrum AC 1944. The staining of eosinophil polymorphs and enterochromaffin cells in histological sections. Journal of Pathology and Bacteriology 56, 441-443.

Leyva V, Henderson AE and Sykes AR 1982. Effect of daily infection with Ostertagia circumcincta larvae on food intake, milk production and wool growth in sheep. Journal of Agricultural Science, Cambridge 99, 249-259.

McAnulty RW, Familton AS, Sedcole RD and Sykes AR 2001. Changes in the resistance of the ewe to infection with Teladorsagia circumcincta during late pregnancy and lactation. Animal Science 72, 159-167.

Miller HRP 1984. The protective mucosal response against gastrointestinal nematodes in ruminants and laboratory animals. Veterinary Immunology and Immunopathology 6, 167-259.

Miyaura $\mathrm{H}$ and Iwata M 2002. Direct and indirect inhibition of Th1 development by progesterone and glucocorticoids. Journal of Immunology 168, 1087-1094.

Monterroso VH and Hansen PJ 1993. Regulation of bovine and ovine lymphocyte proliferation by progesterone: modulation by steroid receptor antagonists and physiological status. Acta Endocrinology 129, 532-535. 


\section{Sykes, Xie, Stankiewicz, Huntley, Mackellar, Sedcole, McAnulty and Green}

Pfeffer A, Douch PGC, Shaw RJ, Gatehouse TK, Rabel B, Green RS, Shirer CL, Jonas WE and Bisset S 1996. Sequential cellular and humoral responses in the abomasal mucosa and blood of Romney sheep dosed with Trichostrongylus axei. International Journal for Parasitology 26, 765-773.

Piccinni MP, Guidizi MG, Biagiotti R, Beloni L, Giannarini L, Sampognaro S, Parronchi P, Manetti R, Annunziato F, Livi C, Romagnani S and Maggi E 1995. Progesterone favours the development of human Thelper cells producing Th2 type cytokines and promotes both IL-4 production and membrane CD30 expression in established Th1 cell clones. Journal of Immunology 155, 128-133.

Raghupathy R 1997. Th1-type immunity is incompatible with successful pregnancy. Immunology Today 18, 478-482.

Roberts CW, Satoskar A and Alexander J 1996. Sex steroids, pregnancyassociated hormones and immunity to parasitic infection. Parasitology Today $12,382-388$.

Robertson TG and Elliott DC 1966. The laboratory assessment of worm parasite populations in sheep. New Zealand Journal of Agricultural Research 9, 350-358.
Sasaki M, Davis CL and Larson BL 1976. Production and turnover of $\lg G 1$ and IgG2 immunoglobulins in the bovine around parturition. Journal of Dairy Science 59, 2046-2055.

Sinski E, Bairden K, Duncan JL, Eisler MC, Holmes PH, McKellar QA, Muurray $\mathrm{M}$ and Stear MJ 1995. Local and plasma antibody responses to the parasitic larval stages of the abomasal nematode Ostertagia circumcincta. Veterinary Parasitology 59, 107-118.

Stankiewicz M and Hadas E 1999. The effect of anthelmintic treatment or immunisation of ewes during pregnancy on the peri-parturient rise in nematode parasite eggs excreted by ewes and on live-weight gain of lambs. Acta Parasitologica 44, 73-78.

Threkeld WL 1934. The life history of Ostertagia circumcincta. Virginia Agricultural Experimental Station Technical Bulletin 52, 1-24.

Xie HL, Stankiewicz M, Huntley JF, Sedcole JR, McAnulty RW, Green RS and Sykes AR 2004. The effects of cold exposure, food allowance and litter size on immunity of peri-parturient sheep to Teladorsagia circumcincta and Trichostrongylus colubriformis. Animal Science 78, 149-158. 